\title{
"LIKE YOU, I WANT TO FEEL EXCITEMENT AND HOPE ABOUT OUR CITY"1: 'CHRISTCHURCH THE CITY' IN CAMPAIGN MATERIAL OF THE 2013 CHRISTCHURCH CITY COUNCIL ELECTION
}

\author{
Sally Carlton \\ Lincoln University, Ellesmere Junction Road/Springs Road, Lincoln, Canterbury, New Zealand \\ E-mail: sallylauracarlton@gmail.com
}

Received 18 November 2013; accepted 03 March 2014

\begin{abstract}
The Christchurch City Council election of 2013 provides a compelling case study through which to consider the interaction between politics and city space. On the one hand, through the careful placement of campaign posters, politics encroached on the physical terrain of the city. On the other hand, candidates included in their campaign material multitudinous references to 'Christchurch the city', demonstrating the extent to which the physical environment of the post-disaster city had become central to local politics.
\end{abstract}

Keywords: Christchurch, city, campaign, election, politics.

Reference to this paper should be made as follows: Carlton, S. 2014. "Like you, I want to feel excitement and hope about our city": 'Christchurch the city' in campaign material of the 2013 Christchurch City Council election, Journal of Architecture and Urbanism 38(1): 11-23.

\section{Introduction}

In September 2013, the city of Christchurch, New Zealand, began to prepare for its triennial Council elections. The month also marked another auspicious occurrence in the life of the city: the three-year anniversary of the 7.1-magnitude earthquake which triggered a powerful and protracted earthquake sequence in the region. Aftershocks have numbered in the tens of thousands, and include the devastating 22 February 2011 earthquake in which 185 people were killed and massive and widespread destruction occurred $^{2}$. On the surface (and this cliché is apt in the case of Christchurch, whose underground infrastructure has been almost totally destroyed by seismic activity), the City Council election and the earthquakes seem unrelated. In reality, however, politics is

1 Buck, V. 2013. Local elections 2013: your vote, your community: Christchurch City Council Riccarton-Wigram Ward, CH041 (20). Christchurch City Council.

2 Between September 2010 and January 2013, almost 4500 aftershocks measuring above magnitude 3 were recorded (GeoNet 2013). thoroughly embedded in the post-disaster urban environment, and vice versa. The physical entity which is 'Christchurch the city' is an undeniably political topic, as are the ongoing effects of the earthquakes ${ }^{3}$.

The 2013 Christchurch City Council election provides a compelling case study through which to consider the interaction between politics and city space. On the one hand, through the careful placement of campaign posters, politics increasingly encroached on the physical terrain of the city as the election date of 12 October drew closer. On the other hand, the multitudinous references to 'Christchurch the city' in candidates' campaign material demonstrated the extent to which the physical environment of the city had become central to local politics. While the city is an important theme in any election, natural disasters can impact

\footnotetext{
3 It has been found that disasters, in addition to being inherently political phenomena in that values are allocated (or not) by governments in the post-disaster phase, have enduring political effects (Drury, Olson 1998: 159).
} 
voter behaviour (Arceneaux, Stein 2006: 50) and the large number of references to Christchurch hints at how fundamental the physical space of the city had become. The centrality of the theme was especially significant given the election's non-compulsory postal vote system; campaign material needed to not only encourage voters to select certain candidates over others, but also rouse adequate interest in the process to encourage voter participation in the first place. The prominence of 'Christchurch the city' in campaign material suggests the concept was deemed highly likely to motivate voters to action.

Through analysis of campaign material employed during the 2013 Christchurch City Council election, this article demonstrates the interrelationship between the physical and political landscapes of the city. It firstly shows how the pre-election instalment of campaign posters brought politics into the urban landscape and in doing so, drew attention to the post-disaster particularities of this landscape. The article then considers candidates' incorporation of 'Christchurch the city' into their official and self-produced campaign material to reveal how the election drew the urban environment into politics. While the majority of these references were verbal, a small number of candidates also used strong visual cues to consciously incorporate the concept into their campaign material.

Two types of campaign material were produced for the 2013 CCC election. Official Candidate Profiles for each of the twelve Mayoral candidates and 54 Ward Councillor candidates (three of whom also ran for Mayor, making a total of 63 Profiles) were published through the City Council. Consisting of a photo and a statement of less than 150 words, these Profiles were intended to provide voters with a brief introduction to each candidate's credentials and policies (Christchurch City Council 2013: 9). The second type of campaign material consisted of advertising commissioned and often designed by the candidates. In comparison to the standardised Profiles, candidates were able to exercise a greater degree of creativity and individuality in their self-produced campaign material, infusing it with their own values, personalities, policy preferences and experiences (Joslyn 1984: 11). This material encompassed a variety of media, including online media (websites and Facebook pages) and traditional media (newspaper adverts, posters, postcards, flyers and business cards).

Circulated around the city and available on the CCC website, the 63 Candidate Profiles were readily accessible (Christchurch City Council 2013b) ${ }^{4}$. In com-

\footnotetext{
4 Christchurch is divided for administrative purposes into seven Wards, with two Councillors and five Board members for each Ward (bar the smaller Banks Peninsula Ward, which is entitled
}

parison, however, candidates' self-produced material was difficult to source. The material was neither available through nor stored at the City Council, such that would-be voters were required to seek out this information themselves. The lack of a centralised 'archiving' system severely restricted voter access to candidates' self-produced material: the distribution of much of this material was targeted to specific electorates (making it difficult for people outside these Wards to learn about other candidates) and citywide dissemination of the material was usually sporadic and short-lived (for example, through adverts in the newspapers). Only a few candidates included in their Profiles or on their flyers an email address or phone number through which more information could be requested, and relatively few candidates created websites and Facebook pages, despite the flexibility of this medium to be updated as the campaign progressed. Only one type of campaign material produced by the candidates was readily and relatively permanently accessible to the majority of the Christchurch population: posters. In addition to analysing the language of candidates' campaign material, this article thus also underscores the pre-eminence of posters in election campaigns despite their relatively limited means of transmitting political information and intent.

Through a combination of requesting material from candidates and documenting posters displayed along arterial roads, the self-produced campaign material of 29 candidates was gathered for analysis (15 complete sets of campaign material and the posters of an additional 14 candidates) $)^{5}$. The material of these 29 candidates included 39 posters, three business cards, eight flyers and eight postcards. Some of this material was shared between two candidates, usually incumbent Councillors from the same ward. Online media were excluded from analysis in this article, as the majority of candidates took down their sites immediately after the election, thus curtailing the possibility of post-election analysis. In recognition of the differences in source sets, two different types of analysis were conducted: Candidate Profiles were analysed for linguistic trends referencing 'Christchurch the city' while the self-produced material was incorporated into the article in support of the first analysis.

to only one Councillor). Although Christchurch residents also vote for Community Board and Canterbury District Health Board members during this election, only the campaign material of candidates nominated for Mayor or Councillor was considered in this article.

5 The author would like to sincerely thank the candidates who provided her with their campaign material for sparing the time and effort to respond to her request. 


\section{Bringing politics into the city}

The instalment of campaign posters for the 2013 Christchurch City Council election very visibly brought politics into the physical landscape of the city, and this action highlighted the particularities of the post-disaster environment. Travelling uncomfortably around the rutted and ruined city streets, past the never-ending rows of road cones and brightly-clad repair teams, in the weeks leading up to the election residents were confronted on almost every corner with posters depicting benignly-smiling Council candidates $^{6}$. Politics in this way infiltrated the physical space of the city, imposing itself on the landscape.

Like other forms of electoral communication, campaign posters are designed to serve particular shortand long-term political goals. The most apparent short-term goal is to encourage voters to select a certain candidate or party over another candidate or party, while long-term benefits of electoral communication include building future support and persuading voters of the correctness of candidates' policy preferences and ideologies (Joslyn 1984: 19-20). Two fundamental elements are crucial to achieve these aims. Firstly and obviously, campaign posters must be displayed. The affixation of posters exposes voters to and familiarises them with candidates; because posters constitute visual indications of the election and the candidate, their presence within the landscape is vital. The second critical component of campaign posters is their content, which incorporates not only the information presented in a poster but also its visual appeal.

Displaying campaign posters is crucial; it is through their physical presence rather than their content that posters have the most political benefit. Research shows that although large numbers of voters are exposed to and indeed, take notice of - campaign posters, they do not use them as a means of identifying preferred candidates. Instead, voters use posters as a means of finding out about the impending election and its contenders (Lewis, Masshard 2002: 375). In other words, campaign posters are used less as tools of advertisement for a candidate or party than as visual indicators of a candidate or party's strength - and thus of their likely election success (Dumitrescu 2011: 942; Seidman 2008: 227). In this way, the prevalence of posters within and across an urban environment is paramount: the more posters, the more a voter can be convinced of a candidate's electoral victory. The motivation behind the placement of campaign posters, therefore, is to

\footnotetext{
6 The classic head-and-shoulders photograph of election candidates keeps viewers at a "safe" distance from their leaders; not too close but not too far away as to lose the personal connection such photographs are intended to symbolise (Seidman 2008: 239).
}

constantly and repeatedly expose voters to potential candidates. Such findings show that, despite the fact that other media better serve to inform voters of candidate or party policy, the display of campaign posters remains ubiquitous campaign procedure. When it can be difficult to access other campaign material, such as the 2013 CCC election, posters play a particularly prominent role.

In stringing up campaign posters, candidates make an obvious statement. The posters serve both as proof of a candidate's decision to run for office, and as a tool to spread awareness and hopefully support for this decision. Yet the physical placement of such material makes another, less explicit statement: in carrying out this action, candidates not only make practical use of a certain space but also lay claim to it $^{7}$. Space in this way becomes a pawn to politics, with candidates rallying to claim the 'best' positions. The installation of campaign posters in Christchurch constituted an additional layer of interaction between physical space and politics, serving not only to visually iterate a candidate's intention to run for office but also to draw attention to the particularities of the city's post-disaster urban landscape.

As tools of advertising, the CCC campaign posters were displayed in obvious and accessible locations where the greatest numbers of passers-by would notice them, such as alongside busy roads or outside local shops. Yet with large tracts of the city still damaged, and with post-disaster demolition and rebuild work in evidence throughout the city, the majority of posters were installed in locations which bore the imprint of the earthquakes of 2010-2011. Indeed, the continued physical omnipresence of the earthquakes within the city - from the twisted skeletal remains of shattered buildings to flat expanses of empty space where buildings once stood - would have made it impossible for candidates to avoid using such spaces.

These reminders of the physical destruction unleashed by the earthquakes were in some instances barely noticeable, for example when campaign posters were nailed to slightly leaning fences (Fig. 1). Alternatively, posters placed in areas of particular desolation unintentionally drew attention to the damage caused by the earthquakes to the city's physical landscape. Such locations included the driveways of deserted and ruined houses, often tagged with graffiti and smothered by encroaching weeds, or in front of large cleared spaces upon which buildings had once stood (Figs 2, 3). Posters were also hung on fences restricting

\footnotetext{
7 Similar observations have been made for other kinds of posters. See for example the chapter 'Outdoor advertising and the symbolic ownership of space' (Aulish, Hewitt 2007).
} 
access to building sites, highlighting the omnipresence of the powerhouse construction companies which are driving the physical - and economic - rebirth of Christchurch (Fig. 4).

Amid the overwhelming damage, and the abundant and often large-scale rebuild projects underway, the installation of campaign posters in one respect only marginally altered the physical environment of Christchurch. Designed and installed with the specific aim of attracting attention, however, the posters did indeed impact upon the urban landscape despite their relatively insignificant size (most of the posters measured less than $1 \times 1.5$ metres). Especially colour played a role in creating this visual impact. Although Christchurch is in some respects a city drenched in fluorescent colour, where high-visibility vests, road cones and roadwork signs constitute the 'new normal', the destroyed and almost perpetually deserted central city and eastern suburbs seem grey even in bright sunshine. The bright colours of the campaign posters injected life into this largely drab landscape.

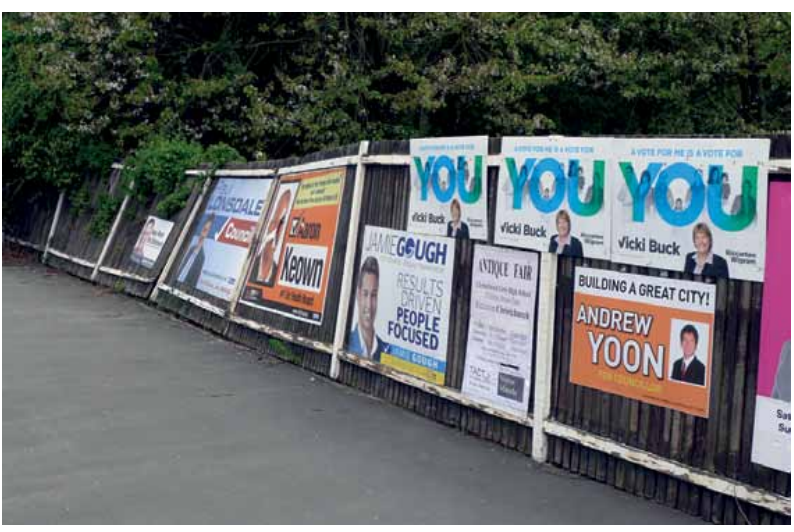

Fig. 1. Campaign posters for 2013 Christchurch City Council candidates adorn a leaning fence (Fendalton Road, Fendalton)

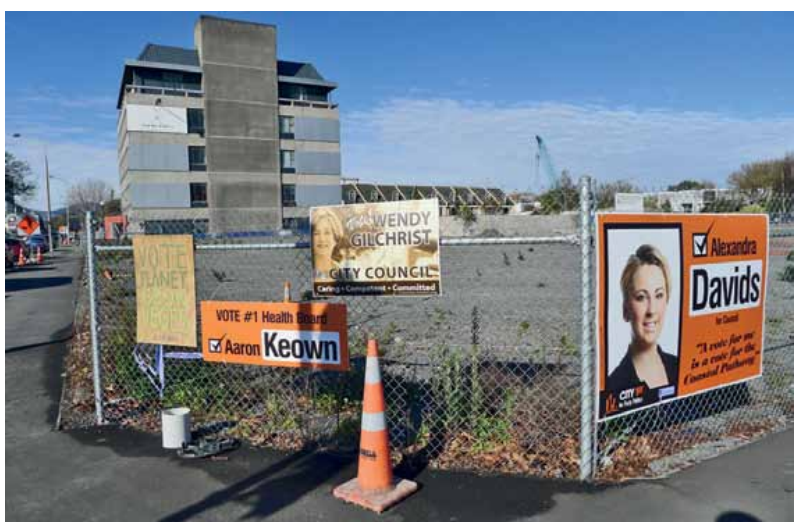

Fig. 3. Campaign posters strung to fencing around a vacant block (corner of Victoria Street and Durham Street North, Christchurch Central)

\section{Bringing the city into politics}

In addition to their physical placement, the second critical element of campaign posters is their content. This element, however, is very much secondary to the all-important issue of poster installation, a truism highlighted by the fact that most campaign posters include only minimal amounts of information. A recent study of Japanese election posters revealed that, although candidates dedicated considerable resources to creating high-quality products, using colour images and catchy slogans, their posters contained little information about either the candidates or their policies (Lewis, Masshard 2002: 374). Name recognition was thus "all-important" (Lewis, Masshard 2002: 391).

This finding rings true for the Christchurch City Council campaign material: the one constant feature of all posters was the candidate's name and photo, with very little extraneous information provided. Some candidates included their ward, political affiliation, slogan or details of a website or Facebook page for interested

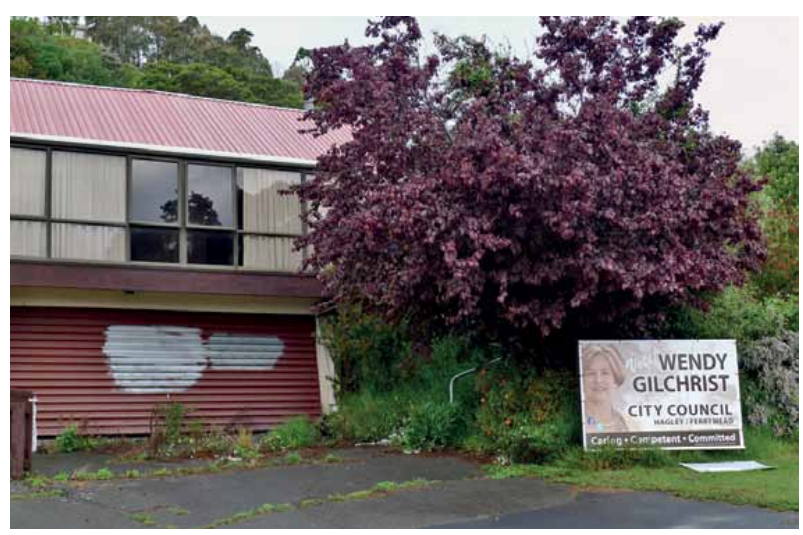

Fig. 2. A poster for Wendy Gilchrist, a candidate for the Hagley-Ferrymead Ward, displayed in front of a condemned house (Main Road, Mount Pleasant)

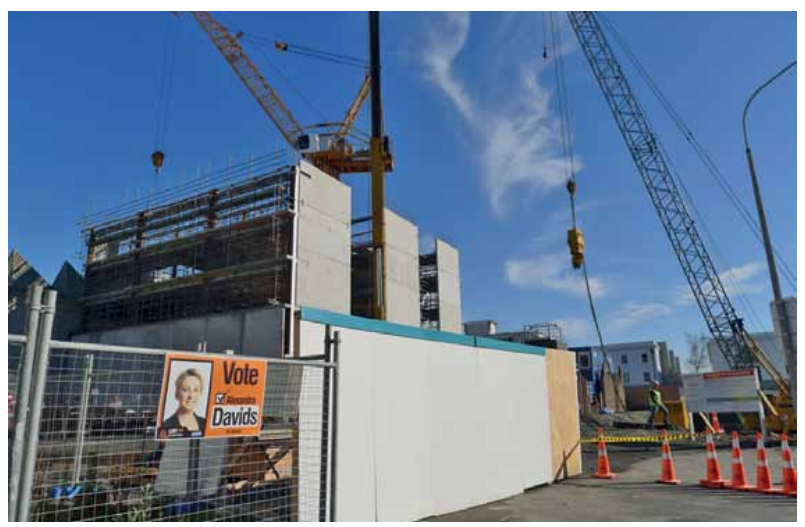

Fig. 4. A poster for Alexandra Davids, standing for the Hagley-Ferrymead Ward, is dwarfed by construction cranes (corner of Durham Street North and Worchester Boulevard, Christchurch Central) 
voters, with only a few candidates choosing to incorporate visual cues or iconography. Given their paucity of information, the posters from the 2013 CCC election contained few references to 'Christchurch the city'. When they did exist, these references were primarily verbal rather than visual, with clever slogans serving as the most powerful means of verbally transmitting city-focussed themes ${ }^{8}$.

Yet although the concept of 'Christchurch the city' was largely absent from campaign posters, it was a prominent - in fact, dominant - theme in other types of campaign material. Both the officially-produced Candidate Profiles and the candidates' self-produced flyers, postcards and business cards heavily referenced the idea. Of the four types of appeal used in electoral communication - appeal based on partisan preference, candidate characteristics, demographic group identities and public policy (Joslyn 1984: 37-38) - the last two techniques were especially used in the CCC election to incorporate the concept of 'Christchurch the city', primarily by highlighting either the post-disaster rebuild needs of a certain group or rebuild issues more generally.

The concept of 'Christchurch the city' in the CCC election encompassed several distinct manifestations, with each embracing a different element of Christchurch's post-disaster physical landscape. Because each manifestation focused on a distinct element of the city's environment, they likely appealed to different sections of the population and thus to different voters. Candidates in this way were able to appeal to both demographic group identities and public policy, often simultaneously. In incorporating 'Christchurch the city' into their campaign material, election candidates endorsed through their choice of words and visuals certain readings of the city's post-disaster landscape. Through inclusion of a particular manifestation of 'Christchurch the city' in campaign material, candidates displayed their personal view on certain post-disaster and rebuild issues, which undoubtedly helped voters determine whether or not to support a particular candidate.

The first manifestation of 'Christchurch the city' was the nostalgic longing for 'Christchurch as historic city' which remembered the city in all its pre-earthquake Gothic glory. This manifestation heavily referenced the city's architectural heritage, much of which was severely damaged by the earthquakes. Debate has raged between parties intent on preserving and restoring heritage buildings and those who favour demolition

\footnotetext{
8 It is usually through slogans that election posters emphasise themes (Seidman 2008: 239).
}

given the very high costs of preservation. Centring particularly around the fate of the "heart of Christchurch", the badly damaged Anglican Cathedral, these debates demonstrate that preservation of urban heritage is vulnerable and constantly changing in relation to context (Markevičienè 2011: 305) 9 .

The second manifestation was the gloomy but powerful manifestation of 'Christchurch as destroyed city', which emphasised the destruction engendered by the earthquakes to the physical environment. It is impossible in Christchurch to remain ignorant of this manifestation of the city, as destruction is omnipresent. Between the crippled ruins of buildings encased by wire fencing and the vast tracts of cleared land where buildings once stood, the physical landscape of Christchurch clearly tells of the disaster it has endured.

Thirdly was the manifestation of 'Christchurch as transitional city'. This concept focused on the inspirational and innovative community-driven urban renewal projects currently transforming the city landscape. These projects are being driven by groups with tellingly descriptive names: Gap Filler, Greening the Rubble and Life in Vacant Spaces are three of the key organisations operating in this arena. Created in response to the physical and social destruction caused by the earthquakes, these groups have developed organically to address perceived 'gaps' in the city's cultural fabric. They source temporarily vacant land (usually sites of demolished buildings still awaiting insurance approval for re-construction) then encourage community engagement to make the space operational. Urban gardens, mobile coffee shops and performance venues are just some of the creative ways in which these groups are revitalising the city. Yet beautifying the physical space is only part of the motivation behind such projects: local involvement in the conceptualisation and physical construction of these spaces is intended to build a sense of togetherness, much needed after the disruption of February 2011.

As a city undergoing construction on an unprecedented scale, the fourth manifestation of 'Christchurch the city' was 'Christchurch as rebuild city'. This concept underscored the opportunity presented by the rebuild for growth in the economic, demographic and other sectors. Symbols of this manifestation were items associated with construction such as road cones, high visibility vests and cranes. This

\footnotetext{
9 The Cathedral is commonly referred to as the "heart of the city". See for example: Christchurch Cathedral... (2013). For an example of the debate around preserving the Cathedral see this recent press release by ICOMOS, the International Council on Monuments and Sites: Cathedral rebuild... (2013).
} 
manifestation, which in its focus on construction and development necessarily revolved around big money and big business, was in contrast to the grassroots-led manifestation of 'Christchurch as transitional city'.

Yet another manifestation was the forward-looking 'Christchurch as city for the future' which stressed the opportunities presented by the tabula rasa of the city space. Sustainability and green living were central concepts to this manifestation, as was physical infrastructure which would allow easy manoeuvrability and access to all residents regardless of traditional restrictions around age, mobility or disability.

In choosing to include reference to 'Christchurch the city' in their campaign material, candidates in the 2103 City Council election consciously decided which words and pictorial cues they would use to portray this concept. These choices served to align them with a particular manifestation of 'Christchurch the city', constituting a tangible declaration of personal or political intent which was then transmitted through official and self-produced campaign material into the public domain. These references - mainly verbal but also visual - demonstrate the extent to which the notion of 'Christchurch the city' was incorporated into the campaign material of 2013 CCC candidates.

Two types of campaign material were analysed for their references to 'Christchurch the city': official Candidate Profiles and candidates' self-produced materials. A quantitative discourse analysis was carried out on the 63 Candidates Profiles to test the centrality of certain keywords to candidates' campaigns, and thus the centrality of these keywords to the election as a whole. Forty-eight keywords were selected based on the concept of the physical entity of 'Christchurch the city', especially taking into account the unique situation of Christchurch as post-disaster landscape. Candidates' self-produced material was also analysed for verbal and visual references to 'Christchurch the city'; however, the incomplete data set prevented a similarly quantitative analysis. Instead, references to 'Christchurch the city' in candidates' self-produced material have been used to further illustrate the findings of the Profile discourse analysis. The results of this dual analysis reveal much about how candidates perceived of and portrayed the city as a physical entity; in other words, with which manifestation of 'Christchurch the city' they identified and the extent to which the concept of 'Christchurch the city' entered the landscape of local politics for the 2013 CCC election. Appendix 1 records the details of the 48 keywords, including the number of times each word was cited, the types of words, and whether the keywords were specific to Christchurch.
By far the most commonly-used word in the Candidate Profiles (with 75 citations) was 'community'. This result is indicative of Christchurch's post-disaster experiences and legacy: in the aftermath of the devastating February 2011 earthquake, with infrastructure and services broken and disrupted, the value of familial, neighbourly and social ties - one's community became apparent. Support groups were rapidly created, and because residents continue to recognise the importance of strong community links, many of these groups are still in operation. The fact that 'people' was with 38 citations the third-most employed word in the Candidate Profiles, and that 'residents' and 'citizens' were also common, serves to reiterate the idea that the basis of a city space is its inhabitants. This idea was espoused by CCC candidate Pauline Cotter, elected to Council for the Shirley-Papanui Ward, whose first policy priority was to "put people at the heart of the recovery" (Cotter 2013).

The word 'city' was the second-most referenced in the Candidate Profiles, with 54 citations. It would appear from the three most regularly-referenced words - community, city and people - that the two major themes of the election were community and the city. Lianne Dalziel, elected Mayor by a landslide margin of almost 50,000 votes ${ }^{10}$, incorporated both these notions into her slogan. In just three words - "One City Together" - her slogan powerfully summed up the widespread desire within Christchurch for connectedness and working together. In fact, Dalziel's campaign rhetoric was very powerfully related to the city: her 150-word Candidate Profile contained 14 keyword references, more than any other Mayoral candidate ${ }^{11}$.

While 'community', 'city' and 'people' could have been keywords common to any election campaign around the world, the large majority of the 48 selected keywords referenced the city space of post-disaster Christchurch, indicating the centrality of the unique urban environment to candidates' advertising. In fact, 10 of the keywords were distinct to Christchurch, 31 of the keywords have taken on particular meaning in Christchurch because of its post-earthquake situation, and only seven of the keywords were generic. Particularly 'rebuild' and 'recovery' - respectively the fourth- and eighth-most cited words in the Candidate

${ }^{10}$ Dalziel received 72,600 votes while the second-highest contender, Paul Lonsdale, received 22,855 votes (Christchurch City Council 2013c).

11 The number of keywords cited by the Mayoral candidates, listed in order from most to least: Lianne Dalziel (14); Hugo Kristinsson (12); Blair Anderson (11); Richard (Rik) Tindall (9); Paul Lonsdale (7); Kyle Chapman and Sammy Harris (6 each); Brad Maxwell (5); Peter Wakeman (4); Victor Cattermole, Tubby Hansen and Robin McCarthy (0 each). 
Profiles - left no doubt that Christchurch was the location for the election. The words were mentioned a total of 47 times, predominantly in relation to a candidate's desire to see the city develop in a particular direction.

A common theme in campaign material was the incorporation of reference to specific urban projects which candidates did or did not support (or, in the case of 2010-2013 Councillors running for re-election, projects they had helped get underway. The most powerful example of this technique was the "Candidate Credibility Checklist" on Ngaire Button's poster, in which she listed the projects she had accomplished during the 2010-2013 Council term (Button 2013) ${ }^{12}$ ). Referencing specific projects allowed candidates to simultaneously appeal to both demographic identities and public policy. Usually these projects related to community facilities rather than infrastructure, and were predominantly specific to certain areas of the city. While the majority of projects were positively referenced, a few candidates mentioned well-known (and well-criticised) government-backed 'Anchor Projects' which they opposed for reasons of expense and priority $^{13}$. Expanding on one of her three policy foci "Putting people before projects" - a candidate for the Spreydon-Heathcote Ward explained: "Christchurch needs a council that delivers great service to ratepayers first, and spends money on legacy projects later" (Riwai-Couch 2013). In choosing to reference - and thus identify with or against - specific projects, candidates not only very clearly delineated their preferences for certain post-earthquake rebuild issues, but also largely revealed their underling philosophies.

One constantly-cited local project was the revitalisation of the residential red zone, a large tract of land in eastern Christchurch deemed uneconomically viable for rebuilding, in part due to the high likelihood of liquefaction in the event of another major earthquake ${ }^{14}$. In particular, the future use of red zone land along the Avon River was under discussion in candidates' campaign material, which was not surprising given the widespread public interest in the site. Grassroots organisations, notably the Avon-Otakaro Network (AvON)

12 On Button's Checklist were: Cycle ways; Cranford footpath pedestrian safety; New skate park for Belfast youth; Free parking at the hospital; Free disability parks city wide; Voted to keep Council assets, with a large DONE! scrawled in orange next to each project.

13 The central government deems its Anchor Projects necessary to attract investment into the city, but many locals believe these projects should not be taking precedence over improving people's everyday living situations (for an investigation into this issue, see for example McCrone 2012).

14 The residential red zone encompasses 7283 properties (CERA 2012b).
(Avon-Otakaro Network 2013), are advocating for the creation of a large park on the site complete with nature trails and commemorative sculptures (most creatively, $\mathrm{AvON}$ is currently harvesting letterboxes from red-zoned homes in order to build ten interpretative artworks along the banks of the river (Meier 20213)) to provide a sanctuary for Christchurch residents and wildlife alike.

Another project to receive specific mention in candidates' campaign material was the Christchurch Coastal Pathway. Part of this recreational walk and cycle track is currently under construction, and supporters hope it will eventually extend 6.5 kilometres along Christchurch's beautiful coastline from the beach suburb of Sumner around the Avon-Otakaro River estuary, connecting into the central city (Christchurch Coastal... 2013). The prominence of this project was obvious in the one of the slogans employed by Alexandra Davids, a candidate for the Hagley-Ferrymead Ward through which the Pathway will run: "A vote for me is a vote for the Coastal Pathway". In asserting her intentions to further the cause of this project, Davids not only clearly indicated her support for the project but also for the much broader issues which underpin it, such as sustainability, accessibility, cyclist safety, commuter comfort and recreational space. In other words, by expressing her support for one specific urban revitalisation project of post-earthquake Christchurch, Davids was able to inform her voters about many of her personal and political opinions and appeal to both voter identity demographics and public policy.

One prominently-cited local venture in the Candidate Profiles was the creation of aquatic facilities in the coastal suburb of New Brighton, an area which sustained especially heavy destruction during the earthquakes. Amongst the irreparably-damaged infrastructure was the QEII waterpark. Replacement of this facility matters greatly to many people (over 20,000 people have signed a petition advocating for the park's creation (New Brighton Waterpark 2013a) ${ }^{15}$ ), who view the project as a key means of breathing life back into that part of the city. The centrality of the issue was so critical to the area that three of the seven candidates for the Burwood-Pegasus Ward (in which New Brighton lies) mentioned 'aquatic facilities' in their Candidate Profiles, accounting for three of the six total mentions for this element of Christchurch's renewal.

One candidate whose Candidate Profile and self-produced material strongly advocated for the construction

\footnotetext{
15 Over the course of the campaign's 24-day life, more than 10,000 signatures were collected online and 10,436 signatures were collected on paper.
} 
of a waterpark in New Brighton was David East, who was elected as one of two Burwood-Pegasus Ward Councillors. Rather than considering 'Christchurch the city' as a whole, East's campaign material was strongly Ward-focussed, but also incorporated many references to 'Christchurch as city for the future.' His Candidate Profile referenced his desire to promote aquatic recreation and cycleways, as well as restore wetlands and create parks and reserves, in order to make BurwoodPegasus "the place where the City comes to play" (East 2013). East further underscored his commitment to the waterpark in his campaign flyer, with two colour photographs of people enjoying the QEII waterpark decorating the left side. Mobile advertising attached to a trailer also incorporated visual reference to the waterpark, visual cues which indicated the centrality of the issue to East's agenda.

David East's Ward-centric rhetoric was echoed by his slogan: "Rebuilding the EAST together". With EAST capitalised to indicate the clever double entendre (and fortuitous alignment) of surname and geographic location, the slogan also made a powerful statement. Christchurch's eastern suburbs were especially badly damaged by the earthquakes, with the result that many residents have had to leave the area in search of safe accommodation. Remaining locals perceive this reduced population as impacting their ability to campaign for change. As was recorded on the New Brighton Waterpark website just two days before the election, "The [Christchurch City Council staff] claim the local catchment is insufficient, that the decrease in population will cause our waterpark to be undersupported." (New Brighton Waterpark 2013b). David East, in focussing his campaign material and especially his slogan on the difficulties faced by residents in Christchurch's east (to the extent of ignoring issues affecting the greater city area), declared his empathy with and dedication to helping local residents, appealing directly to demographic identity and public policy.

Other selected keywords were also specific to the context of post-earthquake Christchurch. Five candidates chose in their Candidate Profiles to reference CERA (the Canterbury Earthquake Recovery Authority, established by the central government to respond to the post-earthquake rebuild), Gerry Brownlee (the government minister in charge of CERA) or other government ministries. Incorporating reference to such agencies or figures plainly delineated a candidate's opinion on the rebuild. Although two of the candidates mentioned CERA in light of its limited lifespan (the Authority is scheduled for closure in 2016, during the mandate of the elected Council), the other three candidates hinted at their displeasure with the current rebuild process, represented by CERA and its minister. This sentiment is not unique to Council candidates; many locals feel they are missing out on their say in the city's future because of the government's seemingly overly top-down approach $^{16}$.

In contrast to the generally negative connotations associated with CERA and its minister, the three candidates whose Profiles referenced either the Student Volunteer Army or its successor, the Volunteer Army Foundation, were mindful of the positive opinions of most locals around these organisations. Responsible for mobilising hundreds of university students following the September 2010 and the February 2011 earthquakes to help with the liquefaction cleanup efforts and disaster relief, the organisations have come to symbolise true grassroots engagement around the quakes and their aftermaths. Claiming affiliation with these groups was thus a powerful means of persuading voters of a candidate's belief in community and commitment to hard work. Candidates who chose to identify themselves with these organisations very powerfully associated with the concept of 'Christchurch as transitional city'; the organisations remain at the forefront of the city's grassroots response to the post-disaster environment through the coordination of community volunteer projects and transitional urban architecture.

One candidate in particular - Raf Manji, elected as one of two Fendalton-Waimari Ward Councillors identified himself with the manifestation of 'Christchurch as transitional city'. Firstly, Manji drew attention in his Candidate Profile to his position as Chair of the Volunteer Army Foundation, one of the most influential post-earthquake groups operating in the transitional city space. Secondly and particularly powerfully, he incorporated into his self-produced campaign material images of key transitional city projects. One of only a few candidates to include a background (instead of blank colour) in his poster, the location was highly symbolic: the Pallet Pavilion (Fig. 5) ${ }^{17}$. This open-air performance and community venue was created in the summer of 2011-2012 by

\footnotetext{
${ }^{16}$ One example of this discontent was an Open Letter sent to Prime Minister John Key by groups protesting against the central government's involvement in the rebuild: "In 2011 a huge number of Cantabrians contributed 106,000 ideas to the Christchurch City Council's 'Share an Idea' campaign for the redevelopment of the inner city. This vast effort by council and citizens was paid mere lip service to by your government and was arrogantly replaced by the CCDU's own Blueprint plan." Rally for Democracy Committee (Save our Schools, IConIC, Historic Places Canterbury, WeCan, Christchurch Civic Trust, Save Hagley Park, TC3 Residents, Water Interests, Wizard of NZ Ltd) (Open Letter... 2012).

17 For information, see: http://palletpavilion.com/.
} 


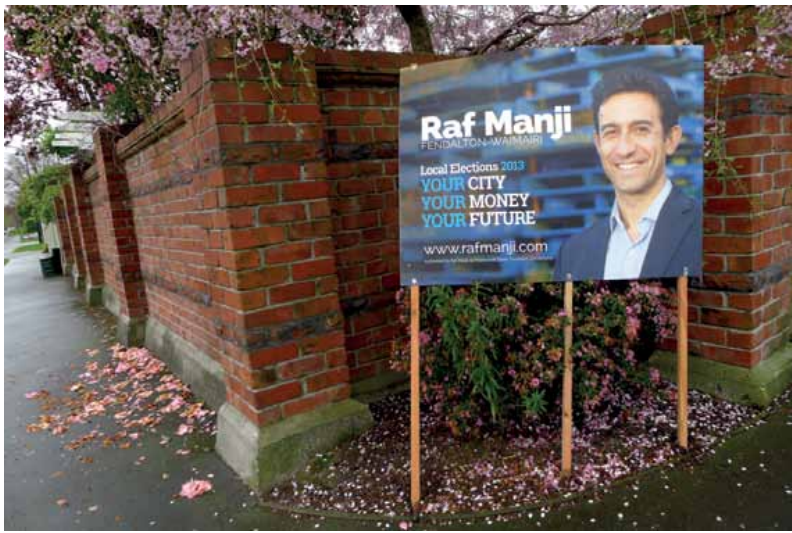

Fig. 5. Raf Manji's campaign poster, picturing him in front of the pinnacle of Christchurch's transitional architecture, the Pallet Pavilion (Fendalton Road, Fendalton)

hundreds of volunteers operating under the guidance of the organisation Gap Filler.

Standing on a key site in the central city, the Pallet Pavilion is a masterpiece of transitional architecture, built out of 3000 overlapping pallets which will re-enter circulation once the structure is eventually demolished. As the largest and most visible Gap Filler project, the Pallet Pavilion is undoubtedly the supreme example of Christchurch's transitional city successes: the site hosts a mobile coffee van and numerous other eateries, as well as offices for several transitional city organisations (constructed by volunteers out of materials salvaged from the red zone). Within the Pavilion are tables and chairs made from fruit boxes, along with games and activities. Acoustic concerts, vintage markets, film nights and other events are regularly held, both to provide space for community engagement and also to encourage people back into the central city area. The Pallet Pavilion is, quite simply, the hub of transitional Christchurch.

In Manji's poster photo, just visible in the out-offocus Pallet Pavilion behind him, are words painted in yellow onto the blue pallets. These words are the names of the hundreds of people from around New Zealand and overseas who in May 2013 donated money through the crowdfunding platform Pledge Me to finance the Pavilion's costs for a year. The significance of the yellow-painted names is thus important: Gap Filler put the question of maintaining the Pavilion for another year to the people, who responded with their donations. Not only is the Pavilion a funky new urban space; the donation of over NZD 80,000 demonstrated the largescale community engagement with and commitment to the space ${ }^{18}$.

\footnotetext{
${ }^{18}$ For the story of the Pledge Me campaign, see: Gap Filler (2013).
}

In using the Pallet Pavilion for his campaign poster photo, Manji tapped into the themes of transition and community inherent to the location. His visual referencing of symbolic sites of Christchurch's urban regeneration was not limited to his poster, however; each of his four postcards, deposited into the letterboxes of Ward voters, relied on imagery with a similarly symbolic meaning. The first postcard replicated the poster, containing Manji's name, ward and slogan against the Pallet Pavilion backdrop. Each of the three subsequent postcards represented an element of Manji's threepronged slogan "Your city; your money; your future". Featured on the second postcard (Strategy) was a photo of a smiling Manji standing in front of the historic $\mathrm{C} 1$ building, which was badly damaged by the earthquakes but has reopened and now houses a popular and funky café, an arthouse cinema and several art galleries. The building itself tells a story of renewal and has become a space for meeting and socialising. The third postcard (Finance) featured EPIC (Enterprise Precinct and Innovation Campus), built in 2012 to provide office accommodation and a central space for innovative local companies which will be "a crucial part of the region's recovery from the earthquakes" according to its website (EPIC 2013). The building is thus symbolic both of the city's regeneration and its commitment to community. The fourth and final postcard (Community) included a photo of a Student Volunteer Army unit working to construct a labyrinth at the site of a demolished church, jubilantly raising their shovels in celebration of their achievements. Urban regeneration and community were thus central to the images Manji included in his campaign material. Identifying strongly with the manifestation of 'Christchurch as transitional city', Manji undoubtedly appealed to a certain voter demographic, people who relate and are contributing to the regeneration of the city's post-earthquake landscape.

On the back of his postcards, Manji expanded on his targeted themes of strategy, finance and community. Encouraging his would-be voters to think about how Christchurch should be led, Manji reminded them on the Strategy postcard that "Share an Idea gave us a vision but the journey to making that happen has barely started" (Manji 2013). Manji's reference to the Share an Idea campaign demonstrates that although the transitional city is his primary domain, he also identifies with 'Christchurch as city for the future'. The Share an Idea campaign was initiated by the Christchurch City Council a few weeks after the February 2011 earthquake with the aim of involving and engaging Christchurch residents' thoughts and hopes for the city's future and rebuild, and has been awarded numerous international prizes for both its 
inventiveness and its openness in responding to a crisis situation ${ }^{19}$. As alluded to in Manji's postcard, locals' initial excitement for the campaign has waned with the passing of time, especially as responsibility for the city rebuild has been progressively given to the central government and CERA. The fate of the Share an Idea campaign is often cited by discontented locals to underscore the top-down approach of Christchurch's post-disaster recovery ${ }^{20}$. Given its significance to discussions around the role of residents in the rebuild, it is surprising that only one candidate (who was not Manji) mentioned Share an Idea in their Candidate Profile (Harnett 2013).

Despite the lack of reference to Share an Idea in the Candidate Profiles, other keywords associated with 'Christchurch as city for the future' were prolific. With 22 citations, 'future' was the fifth-most referenced keyword, used by candidates to outline their visions for the city. Such rhetoric was critical to illustrate to would-be voters the direction in which candidates wanted to move the city. Telling were the highly affirmative adjectives which candidates employed to describe their visions for post-rebuild Christchurch. 'Vibrant', 'exciting', 'inspiring' and 'fresh' are just some of these adjectives, cited by candidates who intended to emphasise their energy and commitment to securing a positive vision for the city's future.

The adjective 'prosperous' was cited only twice in the Candidate Profiles. Jamie Gough, elected in 2013 to represent the Fendalton-Waimairi Ward for a third term, was one of these candidates, reminding his voters that "you've invested in me to rebuild a vibrant, safer and more prosperous Christchurch" (Gough 2013). This same message was evident in his campaign posters. While the word 'prosperous' was present neither in the information on his posters nor in the multiple slogans he employed, the very placement of his posters drew attention to the idea. In a city currently undergoing demolition and rebuilding on a mammoth scale, prosperity is undeniably linked to construction. Gough's campaign posters, displayed more prominently than any other candidate in his Ward because they adorned the fences of large-scale building companies, stood as visible testaments to the connections between the rebuild and (the potential for) prosperity (Fig. 6).

${ }^{19}$ In 2011, Share an Idea was voted "unanimous overall winner" of the Netherlands-based Co-creation Association's Cocreation Award (Christchurch City Council 2011). Share an Idea was also awarded one of four Winner prizes in the Virserum Art Museum's Triennal Architecture of Necessity Awards (Anon 2013)

20 "What came of the 'share an idea', ideas? anything [sic] or was that a waste of our energy?" wondered an observer recently on the initiative's Facebook page (Prendeville 2013).
In underscoring the issue of prosperity and in obviously linking this idea with the construction companies driving the rebuild, Gough identified very clearly with the manifestation of 'Christchurch as rebuild city'. Two other candidates to similarly associate themselves were Ngaire Button and Aaron Keown, although their visual referencing of the rebuild had none of Gough's subtlety. One of their shared campaign posters pictured them, as incumbent Councillors of the Shirley-Papanui Ward, wearing hard hats and high-visibility vests, poring studiously over construction plans. The photo, as well as the slogan "Our city, our rebuild" (Fig. 7), implied that the Councillors were fruitfully contributing to the direction of the rebuild, a notion which very obviously brought 'Christchurch the city' into politics. Another candidate whose slogan referred to the physical act of rebuilding the city was Matthew Carpenter, who played with great effect upon his surname to inform his voters that "Christchurch needs a good carpenter" (Carpenter 2013). Few other candidates, however, referenced the rebuild as an overarching phenomenon; the rebuild was approached predominantly through reference to specific projects.

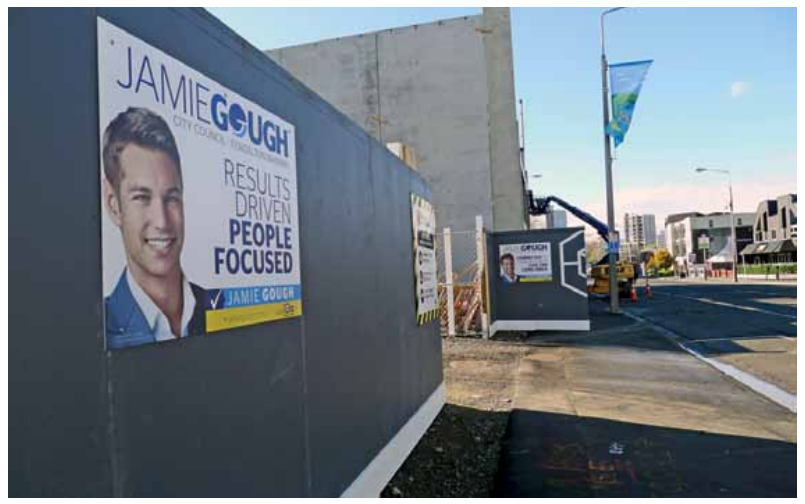

Fig. 6. Jamie's Gough's posters co-exist with construction signs (Durham Street North, Christchurch Central)

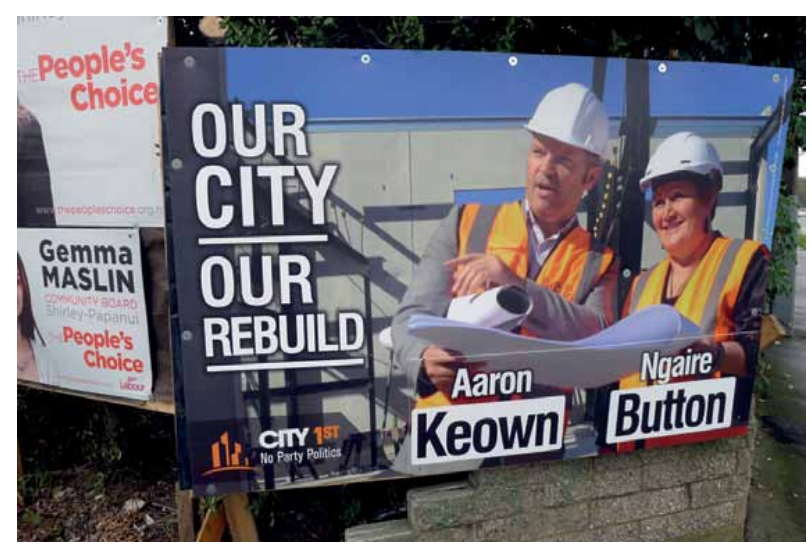

Fig. 7. Incumbent Councillors Aaron Keown and Ngaire Button driving the rebuild (corner of Bealey Avenue and Madras Street, Christchurch Central) 
The contextual particularities of post-earthquake Christchurch mean that the repetition of certain keywords in the Candidate Profiles was expected; yet it is precisely this unique situation which rendered the minimal employment of other keywords surprising. Despite the prominence of future-focussed rhetoric, there were for example only 12 references to 'sustainability / sustainable' and nine references to 'environment / environmental'. These relatively low figures are incongruous for two reasons. Firstly, the necessary rebuild of almost the entire Central Business District means that Christchurch is faced with an inimitable opportunity to capitalise upon and implement environmentally-sound designs and techniques in order to create a thoroughly 'green' city. Secondly, there is a real and obvious desire amongst city residents that such visions be fulfilled, as demonstrated by the number of community groups devoted to discussion and debate around such topics ${ }^{21}$.

Also rarely mentioned in Candidate Profiles were certain words which surface continually in contemporary rhetoric around the concept of 'Christchurch the city', including 'wellbeing' (with six references), 'opportunity' (five references) and 'accessibility' (one reference). These words have all been omnipresent in recovery discourse over the three years since the earthquakes, particularly in documents produced by the central government and CERA ${ }^{22}$. At this stage in the post-disaster recovery process, with many residents still living in damaged housing and tiring from ongoing insurance battles, mental health and wellbeing is a key concern (one initiative in acknowledgement of this issue is CERA's six-monthly Wellbeing Surveys between August 2012 and the end of 2014 (CERA 2012a: 3)). As a catchword of the moment, 'wellbeing' is noticeably missing from the overwhelming majority of Candidate Profiles. In eschewing such well-worn rhetoric, candidates distanced themselves from existing recovery programmes, tending instead to reference their visions for post-rebuild Christchurch.

\footnotetext{
${ }^{21}$ Some of the many community-led organisations advocating for a particular vision for post-rebuild Christchurch include: Christchurch for the Future (http://www.facebook.com/Christc hurchForTheFuture?ref=ts\&fref=ts); Christchurch of the Future (http://www.facebook.com/pages/Christchurch-of-the-Futur e/304987512892950? ref=ts\&fref=ts ); Eastern Visions (http:// www.rebuildchristchurch.co.nz/Eastern-Visions/Home); and The Future of Christchurch (http://www.facebook.com/groups/ future.of.Christchurch/?ref=ts\&fref=ts).

${ }^{22}$ One key example of a government-produced document which heavily references "opportunity" and "accessibility" is the Land Use Recovery Plan (LURP): Environment Canterbury, et al. 2013. Draft Land Use Recovery Plan - Te Mahere Whakahaumanu Tāone, 5 July, 2013.
}

\section{Conclusion}

In incorporating reference to 'Christchurch the city' into their campaign material, candidates normally identified with one of five manifestations of the postearthquake environment: 'Christchurch as historic city', 'Christchurch as destroyed city', 'Christchurch as transitional city', 'Christchurch as rebuild city' or 'Christchurch as city for the future'. Other than in references to the preservation of the city's heritage (including buildings of particular symbolic significance), the majority of candidates preferred not to dwell on the past; manifestations of 'Christchurch as historic city' and 'Christchurch as destroyed city' were rare. Allusions to Christchurch's transitional scene, used to great effect by Raf Manji, were absent from the material of almost every other candidate. Likewise, although the rebuild was central to the campaign material of many candidates, it was mainly incorporated through reference to individual key projects rather than as an overarching phenomenon. The most prominent manifestation of 'Christchurch the city' in candidates' campaign material, then, was the forward-focussed 'Christchurch as city for the future'. The dominance of this particular manifestation of Christchurch to the campaign material suggests candidates envisaged the election as a means of influencing the city's post-disaster rebuild to positively impact on the future.

The 2013 Christchurch City Council election provides a thought-provoking case study through which to consider the interaction between urban space and politics. The placement of campaign posters around the city in the lead-up to the election served to bring politics into the space of the city (and simultaneously draw attention to the particularities of this post-disaster space), while candidates' official and self-produced campaign material heavily referenced the physical entity of 'Christchurch the city', thus bringing the city into politics. The many references to 'Christchurch the city' in candidates' campaign material underscore the centrality of the city's urban environment to local politics. Candidates' tendency for future-focussed commentary possibly hints at discontent with the current rebuild process, but also suggests boundless positivity and hope for the physical entity which is post-disaster 'Christchurch the city'.

\section{References}

Anon. 2013. Winners and Honorary Mentions in the Triennal Architecture of Necessity announced, 27 June, 2013 [online], [cited 7 July 2013]. Available from Internet: http://www. virserumskonsthall.com/php/index.php?object\&id=247\&catid $=17 \& \mathrm{l}=$ 
Arceneaux, K.; Stein, R. M. 2006. Who is held responsible when disaster strikes? The attribution of responsibility for natural disaster in an urban election, Journal of Urban Affairs 28(1): 43-53. http://dx.doi.org/10.1111/j.0735-2166.2006.00258.x

Aulish, J.; Hewitt, J. 2007. Seduction or instruction? First World War posters in Britain and Europe. Manchester, New York: Manchester University Press.

Avon-Otakaro Network [online], [cited 1 November 2013]. Available from Internet: http://www.avonotakaronetwork.co.nz/

Button, N. 2013. Candidate for the Shirley-Papanui Ward, campaign poster.

Carpenter, M. 2013. Candidate for the Hagley-Ferrymead Ward, campaign poster, flyer and business card.

Cathedral rebuild ignores opportunity, ICOMOS, 17 September, 2013 [online], [cited 9 November 2013]. Available from Internet: http://www.scoop.co.nz/stories/AK1309/S00573/ cathedral-rebuild-ignores-opportunity.htm

CERA (Canterbury Earthquake Recovery Authority). 2012a. CERA Wellbeing Survey 2012 Report.

CERA (Canterbury Earthquake Recovery Authority). 2012b. Red zone offers a roaring success, 15 June [online], [cited 20 July 2013]. Available from Internet: http://cera.govt.nz/ news/2012/red-zone-offers-a-roaring-success-15-june-2012

Christchurch Cathedral restoration, Great Christchurch Buildings Trust, 23 August, 2013 [online], [cited 1 November 2013]. Available from Internet: http://www.scoop.co.nz/stories/ AK1308/S00706/christchurch-cathedral-restoration.htm

Christchurch City Council. 2011. "Share an Idea" wins international award, 24 November, 2011 [online], [cited 7 July 2013]. Available from Internet: http://www.ccc.govt.nz/ thecouncil/newsmedia/mediareleases/2011/201111241.aspx

Christchurch City Council. 2013a. Local elections 2013. Christchurch City Candidate Information Booklet.

Christchurch City Council. 2013b. [Online], [cited 18 October 2013]. Available from Internet: http://www.ccc.govt.nz/

Christchurch City Council 2013c. [Online], [cited 20 October 2013]. Available from Internet: http://www.ccc.govt.nz/ thecouncil/newsmedia/mediareleases/2013/201310181.aspx

Christchurch Coastal Pathway [online], [cited 1 November 2013]. Available from Internet: http://www.christchurchcoastalpathway.org.nz/

Cotter, P. 2013. Candidate for the Shirley-Papanui Ward, campaign postcard.

Drury, A. C.; Olson, R. S. 1998. Disasters and political unrest: an empirical investigation, Journal of Contingencies and Crisis Management 6(3): 153-161. http://dx.doi.org/10.1111/1468-5973.00084

Dumitrescu, D. 2011. The importance of being present: election posters as signals of electoral strength, evidence from France and Belgium, Party Politics 18(6): 941-960. http://dx.doi.org/10.1177/1354068810389644

East, D. 2013. Local elections 2013: your vote, your community: Christchurch City Council Burwood-Pegasus Ward, CH031 (20). Christchurch City Council.

EPIC [online], [cited 1 November 2013] http://www.epicinnovation.co.nz/about-epic/.

GeoNet, Aftershocks [online], [cited 24 July 2013]. Available from Internet: http://info.geonet.org.nz/display/home/ Aftershocks

Gap Filler. 2013. You did it! Pavilion to STAY!, 20 May, 2013 [online], [cited 1 November 2013]. Available from Internet: http:/palletpavilion.com/pledge-me-fundraising-campaign/
Gough, J. 2013. Local elections 2013: your vote, your community: Christchurch City Council Fendalton-Waimairi Ward, CH021 (20). Christchurch City Council.

Harnett, S. 2013. Local elections 2013: your vote, your community: Christchurch City Council Riccarton-Wigram Ward, CH041 (22). Christchurch City Council.

Joslyn, R. 1984. Mass media and elections. Random House: New York.

Lewis, J.; Masshardt, B. J. 2002. Election posters in Japan, Japan Forum 14(3): 373-404.

Manji, R. 2013. Candidate for the Fendalton-Waimairi Ward, 'Strategy' campaign postcard.

Markevičienè, J. 2011. Protection of human rights to the city and preservation of historic urban landscapes: ways to coherence, Town Planning and Architecture 35(4): 301-309. http://dx.doi.org/10.3846/tpa.2011.32

McCrone, J. 2012. The centre that rules the city, The Press 15 December [online], [cited 1 August 2013]. Available from Internet; http://www.stuff.co.nz/the-press/christchurch-life/8083884/The-centre-that-rules-the-city

Meier, C. 2013. Harvesting red zone letterboxes for art, The Press 21 October [online], [cited 1 November 2013]. Availabe from Internet: http://www.stuff.co.nz/the-press/ news/christchurch-earthquake-2011/9305950/Letterboxestell-stories-of-lost-homes

New Brighton Waterpark. 2013a. Over 10,000 signatures ONLINE!! (February) [online], [cited 1 November 2013]. Available from Internet: http://www.newbrightonwaterpark.co.nz/

New Brighton Waterpark. 2013b. New Brighton Water ParkCreated by Visionaries, Scuttled by Positionaries, 10 October, 2013 [online], [cited 1 November 2013]. Available from Internet: http://www.newbrightonwaterpark.co.nz/

Open Letter to the Prime Minister of New Zealand, 1 December, 2012. [Online], [cited 31 July 2013]. Available from Internet: http://www.rebuildchristchurch.co.nz/blog/2012/12/openletter-to-the-prime-minister-of-new-zealand-democracy.

Prendeville, S. 2013. Share an Idea. Facebook page, 14 June, 2013 [online], [cited 21 July 2013]. Available from Internet: http://www.facebook.com/shareanidea.org.nz

Riwai-Couch, M. 2013. Candidate for the Spreydon-Heathcote Ward, campaign postcard.

Seidman, S. A. 2008. Posters, propaganda, persuasion in election campaigns around the world and through history. New York: Peter Lang.

\section{SALLY CARLTON}

Lincoln University, Ellesmere Junction Road/Springs Road, Lincoln, Canterbury, New Zealand.

E-mail: sallylauracarlton@gmail.com

Having completed a PhD in French History from the University of Western Australia (UWA), Sally spent 2011-2012 working as a Research Fellow at the Nepal Institute for Policy Studies (NIPS) with the Australian Youth Ambassador for Development (AYAD) programme. She has since moved to Christchurch, New Zealand, where she is doing a postdoctorate at Lincoln University investigating the notion of 're-humanising sustainability' and working part-time at the Canterbury Refugee Council. Her research interests include curricula, commemoration, urban regeneration, democratisation and human rights. 


\section{Appendix 1}

Keywords cited in the Candidate Profiles

\begin{tabular}{|c|c|c|c|c|}
\hline Ranking & Keyword & $\begin{array}{c}\text { Number } \\
\text { of times cited }\end{array}$ & Type of word & $\begin{array}{l}\text { Specific to } \\
\text { Christchurch? }\end{array}$ \\
\hline 1 & community & 75 & noun & $\mathrm{N}$ \\
\hline 2 & city & 54 & noun & $\mathrm{N}$ \\
\hline 3 & people & 38 & noun & $\mathrm{N}$ \\
\hline 4 & rebuild / build & 28 & noun / verb & $\mathrm{Y}$ \\
\hline 5 & future & 22 & noun & $(\mathrm{Y})$ \\
\hline 6 & new / renewed / fresh & 21 & adjective & $(\mathrm{Y})$ \\
\hline 7 & housing / homes & 20 & noun & $(\mathrm{Y})$ \\
\hline 8 & recovery / recover & 19 & noun / verb & $\mathrm{Y}$ \\
\hline 9 & earthquake / post-earthquake & 15 & noun / adjective & $\mathrm{Y}$ \\
\hline 10 & vibrant / energetic / exciting / excitement / vitality & 13 & adjective & $(\mathrm{Y})$ \\
\hline 11 & residents & 12 & noun & $\mathrm{N}$ \\
\hline 11 & sustainability / sustainable & 12 & noun / adjective & $(\mathrm{Y})$ \\
\hline 11 & water / waterways / rivers / wetlands & 12 & noun & $(\mathrm{Y})$ \\
\hline 14 & facilities & 10 & noun & $(\mathrm{Y})$ \\
\hline 14 & traffic / transport / parking & 10 & noun & $(\mathrm{Y})$ \\
\hline 16 & environment / environmental & 9 & noun / adjective & $(\mathrm{Y})$ \\
\hline 16 & health / healthy & 9 & noun / adjective & $(\mathrm{Y})$ \\
\hline 18 & citizens & 8 & noun & $\mathrm{N}$ \\
\hline 19 & affordable / economical & 7 & adjective & $(\mathrm{Y})$ \\
\hline 19 & heritage / history & 7 & noun & $(\mathrm{Y})$ \\
\hline 19 & safety / safe & 7 & noun / adjective & $\mathrm{N}$ \\
\hline 22 & aquatic facilities & 6 & noun & $(\mathrm{Y})$ \\
\hline 22 & wellbeing & 6 & noun & $\mathrm{Y}$ \\
\hline 24 & CERA / Brownlee / government agencies & 5 & noun & $\mathrm{Y}$ \\
\hline 24 & infrastructure & 5 & noun & $(\mathrm{Y})$ \\
\hline 24 & opportunity & 5 & noun & $(\mathrm{Y})$ \\
\hline 24 & parks / green spaces & 5 & noun & $(\mathrm{Y})$ \\
\hline 28 & cycleways & 4 & noun & $(\mathrm{Y})$ \\
\hline 28 & invigorate / revitalise / revitalisation & 4 & verb / noun & $(\mathrm{Y})$ \\
\hline 28 & urban planning / urban design / urban enhancement & 4 & noun & $(\mathrm{Y})$ \\
\hline 31 & Student Volunteer Army / Volunteer Army Foundation & 3 & (concept) & $\mathrm{Y}$ \\
\hline 31 & clever / smart & 3 & adjective & $(\mathrm{Y})$ \\
\hline 31 & climate / air quality & 3 & (concept) & $\mathrm{N}$ \\
\hline 31 & funky / characterful & 3 & adjective & $(\mathrm{Y})$ \\
\hline 31 & roads & 3 & noun & $(\mathrm{Y})$ \\
\hline 36 & disaster & 2 & noun & $\mathrm{Y}$ \\
\hline 36 & liveable & 2 & adjective & $(\mathrm{Y})$ \\
\hline 36 & identity / sense of place & 2 & noun & $(\mathrm{Y})$ \\
\hline 36 & Garden City & 2 & noun & $\mathrm{Y}$ \\
\hline 36 & hope & 2 & noun & $(\mathrm{Y})$ \\
\hline 36 & prosperous & 2 & adjective & $(\mathrm{Y})$ \\
\hline 42 & Share an Idea & 1 & (concept) & $\mathrm{Y}$ \\
\hline 42 & inspiring & 1 & adjective & $(\mathrm{Y})$ \\
\hline 42 & energy & 1 & noun & $(\mathrm{Y})$ \\
\hline 42 & accessible / accessibility & 1 & adjective / noun & $(\mathrm{Y})$ \\
\hline 42 & libraries & 1 & noun & $(\mathrm{Y})$ \\
\hline 42 & community centres & 1 & noun & $(\mathrm{Y})$ \\
\hline 42 & transitional city & 1 & (concept) & $\mathrm{Y}$ \\
\hline$=48$ & & $=486$ & & $\begin{array}{c}N=7 \\
Y=10 \\
(Y)=31\end{array}$ \\
\hline
\end{tabular}

Notes: $\mathrm{N}=$ Keyword is not specific to Christchurch;

$Y=$ Keyword is specific to Christchurch because of its experiences of the earthquakes;

$(Y)=$ Keyword is not strictly specific to Christchurch but is of primary concern in Christchurch because of its experiences of the earthquakes. 